TP Periodica Polytechnica Civil Engineering

61 (4), pp. 740-751, 2017

https://doi.org/10.3311/PPci.9090

Creative Commons Attribution (i)

RESEARCH ARTICLE

\section{A Review of Direct Shear Testing Configurations for Bond between Fiber-Reinforced Polymer Sheets on Concrete and Masonry Substrates}

\author{
Behnam Shadravan $^{1 *}$, Fariborz M. Tehrani ${ }^{2}$
}

Received 15 February 2016; Revised 09 December 2016; Accepted 31 January 2017

\begin{abstract}
The surface bond characteristics of Fiber-Reinforced Polymer (FRP) sheets have been subject to research for more than two decades. These sheets generally exhibit brittle performance during direct shear and often delaminate prematurely before they attain the full strength of the material. This paper reviews the experimental testing configurations to investigate the direct shear bond surface characteristics of FRP sheets on concrete and masonry substrates. Additionally, it summarizes the data acquisition methods and the observed behavior for surface bond of FRP sheets on concrete and masonry. This review aims to serve as a source for future experimental research studies in the field. Further, an innovative testing configuration is suggested to measure bond strength of FRP sheets on concrete and masonry surfaces in direct shear.
\end{abstract}

\section{Keywords}

direct shear bond test, FRP shear bond, shear bond test setup

\section{${ }^{1}$ Division of Engineering Technology}

Construction Engineering Technology Program

Florida A\&M University

Room 205, 1339 Wahnish Way, Tallahassee, FL 32307, USA

${ }^{2}$ Department of Civil \& Geomatics Engineering

California State University, Fresno College of Engineering

2320 E. San Ramon Ave., MS/EE94, Room E196 Fresno

CA 93740-8030, USA

*Corresponding author, email: behnam.shadravan@gmail.com

\section{Introduction}

Application of surface-bonded fiber-reinforced polymer (FRP) sheets is an attractive retrofit technique to achieve deformation control and improved strength in brittle masonry and concrete vertical and horizontal structural members.

The surface bond characteristics of FRP sheets have been a topic of research in last decades. The sheets exhibit brittle performance and often delaminate prematurely before they attain the full strength of materials.

Based on the previous research and observed behavior of FRP bond failures, it may be concluded that following parameters affect the surface bond [1];

I. Base material characteristics: type, strength; and surface roughness and condition [2, 3];

II. FRP sheet characteristics: type, mechanical properties, thickness, number of layers, and width;

III. Epoxy resin properties: strength, elongation, and thickness;

IV. Loading type: monotonic/cyclic and static/dynamic; including the effects of seismic, fatigue, blast, etc. [4-6];

V. Environmental conditions: temperature [7, 8], frosting and Freeze-thaw [9], humidity [10], and pollution

Shadravan et al. (2007) hypothesized that the testing method and setup in experimental studies changes the way that loading conditions and the fracture mechanism are modeled in the study, and thus, affects the interpretation of results. This paper reviews available testing procedures and configurations and proposes a new method for direct shear testing method [11].

\section{Testing Methods and Configurations for Concrete Substrates}

Different testing setups and methods are available to investigate the bond behavior and debonding failures of surface bonded FRP sheets [7, 10-36]. These testing configurations can be classified into four categories on the basis of the type of stresses generated in concrete: I) tension; II) direct or pure shear; III) combined shear and tension; and IV) flexure. The direct shear test is the most effective method to evaluate the bond characteristics of fiber-concrete interface. Shadravan et al. (2007) summarized the direct shear tests [11], as shown in Fig. 1 (after [37-39]). 
(a) double shear pull tests;
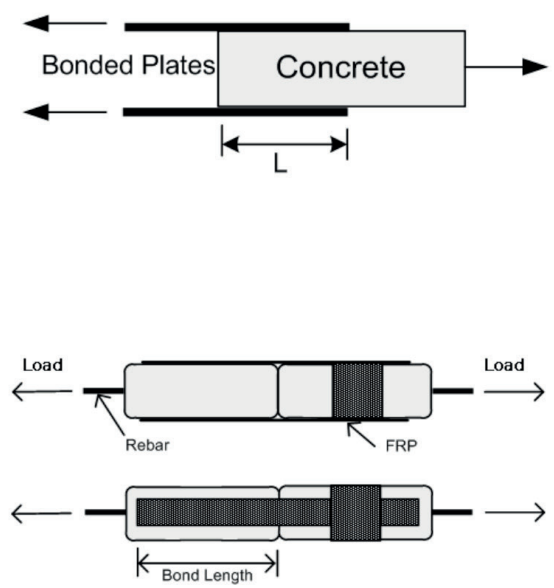

(II) single lap type:

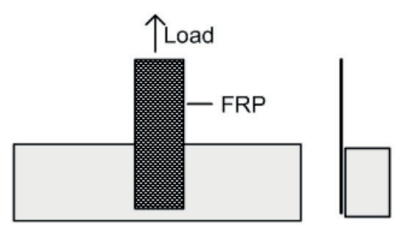

(c) single shear pull test;

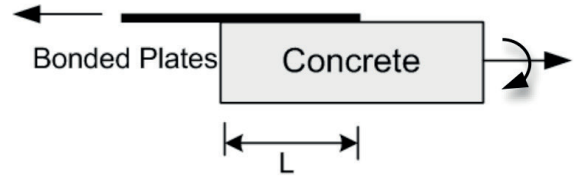

(b) double shear push tests,
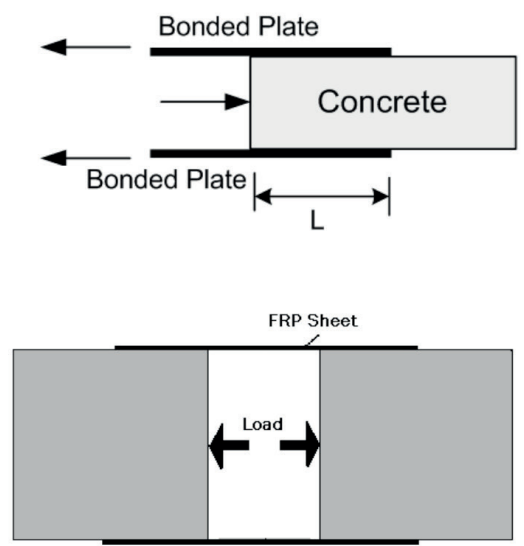

(d) single shear push tests;

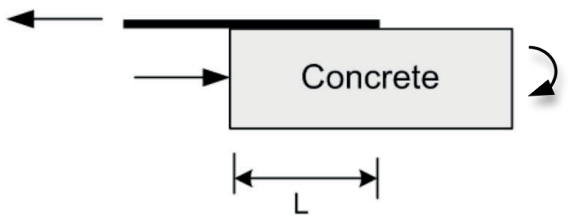

Fig. 1 Types of direct shear bond tests [11] (after Yao et al. 2005[37], NakabaK et al. 2001b [38] and Chen et al. 2001 [39]

Test setups used for direct shear bond tests can be classified into two groups: double lap type and single lap type. The double lap type is implemented either as double shear pull (Double Pull) tests, also called Far End Supported (FES) double-shear tests; and double shear push tests (Double Push), also called Near End Supported (NES) double-shear tests. Single lap type tests are conducted either as single shear pull (Single Pull) tests, which may also be called Far End Supported (FES) single-shear tests; or single shear push tests (Single Push), which may also be called near end supported (NES) single-shear tests. In all of these test setups the FRP sheet is pulled directly by a tensile force. Collectively, all these four tests may be referred to as pull tests, as FRP sheet is always directly pulled by a tensile force.

The "double shear pull test" and the "single shear push test", shown in Fig. 1 (a) and Fig. 1(d), are the most commonly used test methods among researchers because of their simplicity [4, 37-42]. However, the state of stress in the concrete in each of these two test methods can be expected to be quite different. Therefore, significant difference exists between these two methods. The single shear push test offers savings in both material and labor because only one coupon is bonded to the concrete [39]. The double pull tests are more suitable for standard universal testing machines, which enable the application of different loading procedures at different loading speeds, including cycling loading and fatigue tests. This is one reason why they are used commonly among researchers $[13,23$, 42-52]. In this test setup, two FRP sheets are bonded on opposing sides of a concrete block with equal tensile forces applied to each sheet. This pulling force may be applied either through a steel bar embedded in concrete or through steel plates bonded on the sides of the concrete block [39].

The single push tests in figure 1(d) are the second most popular tests after the double pull tests. This method was implemented in various researches [4, 14, 24, 27, 30, 37, 46, 53-60].

In a double push test (Fig. 1b), the pushing force exerted on the concrete block is usually applied through a hydraulic jack $([61,62]$. The stresses generated in this setup are applied through compressive forces applied on concrete, as opposed to tensile forces applied on FRP, as in the case of Double Pull test. This difference may lead to discrepancies among test results, such as the observed mechanism of fracture [39].

The single pull test, shown in Fig. 1(c), has not been used in the past, though the test set-up was mentioned by Chen et al. (2001) [39]. In this case, only one FRP sheet is bonded on one side of the concrete block. This leads, however, to a loss of symmetry, unlike the double pull test. 

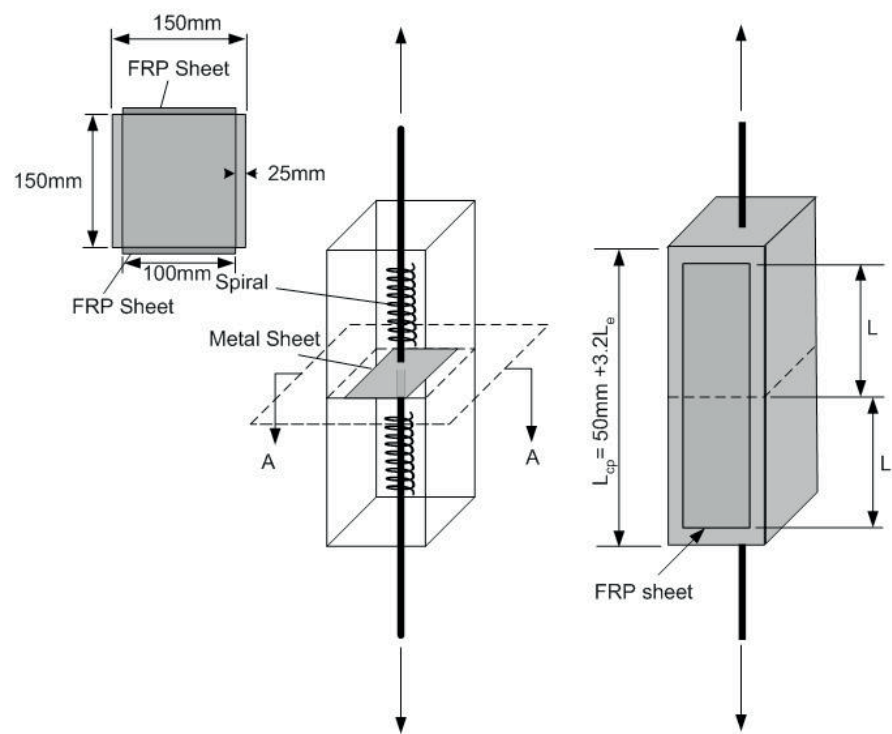

(a) Method A: double shear pull out test

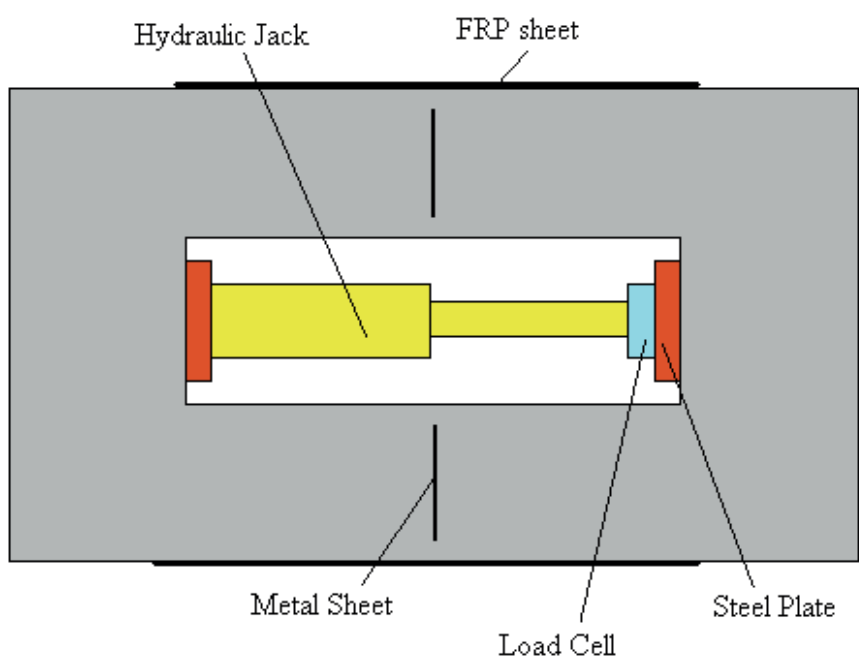

(b) Method B: push apart double shear test

Fig. 2 Concrete bond test (redrawn from Recommend in Annex P CSA S806-02 ) [64]

The ACI 440.2.R (2008) provides Guidance for the design and construction of externally bonded FRP systems for strengthening concrete structure [63]. This reference uses well known expressions for the direct shear bond behavior, but excludes the pull-out test for investigation of direct shear behavior of FRP on concrete. The standard tests recommended in Annex P of the Canadian Standard Association's CSA S806 (2002) includes direct tension tests [64]. Fig. 2 shows test set-ups and methods recommended by this reference. In this figure, Method A and Method B depict a double shear pull-out test and a push apart double shear test, respectively.

Shadravan et al. (2007) modified CSA testing method and introduced an innovative double shear push test setup and tested 12 specimens [11]. The specimen geometry is illustrated in Fig. 3. In this method, the concrete is pushed away by the steel plate. A relatively thick steel plate is welded to the rebar to maintain the elastic rigidity for pushing load during testing.
The welded steel plates were added to the rebars in order to avoid the anchorage rupturing of the rebars. The tests later showed that the bond failure occurs in lower loads than implementing of the anchorage failure. So the steel sheets were not used anymore.
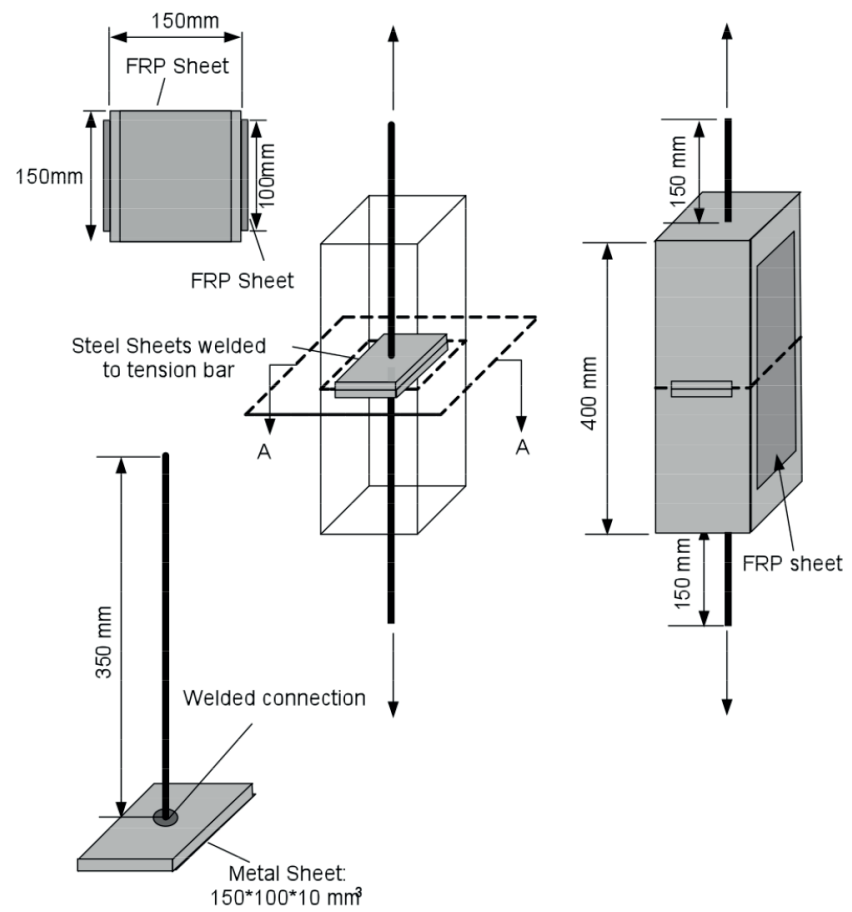

Fig. 3 Schematic view of double shear push test setup by Shadravan et al. (2007) [11]

Another pullout setup was implemented with U-shaped FRP sheets. The FRP sheet is continuous on one side of the specimen, and allows two bond lengths to be tested at the same time. This reduced the likelihood of introducing a defect (one in two) and also reduces the instrumentation to be used per specimen, while promoting a more accurate test procedure. Therefore, the new test setup, referred to it as; "U-shaped Pull Test," was implemented for the remaining tests. Fig. 4 illustrates schematics of a typical U-shaped pull test (Shadravan 2010 [1]).

The results of numerical and experimental studies indicate that testing configurations affect test results [37, 39]. Little difference can be expected between the double and single shear push tests, and between the double and single shear pull tests [39]. Furthermore, it has also been reported that small variations in test setups within a selected method, such as the height of the support block, may also have significant effects on the bond behavior [39]. 


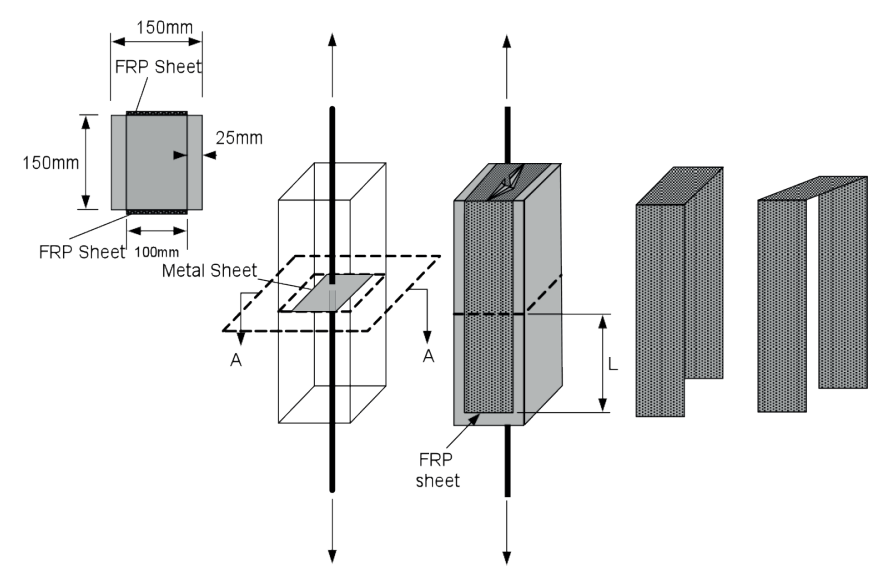

Fig. 4 The schematic view of test specimens with U-shaped FRP strips by Shadravan 2010 [1]

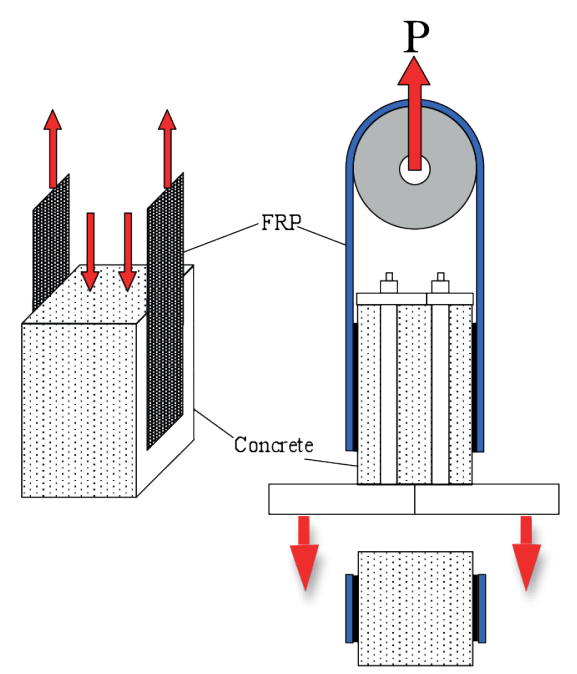

Fig. 5 Redrawn Double shear push bond test setup used by Haddad et al. (2013) [2]. The method already used by Briccoli Bati et al. (2009) [73] for testing brick specimens

Typical double shear testing method (both pull and push test) is symmetric, such that the two substrates of concrete (or masonry), is used for a test. So the weight of the typical double shear test is twice of the similar single shear specimen. This may lead to problems with handling, carrying, and the need for additional data acquisition systems. Haddad et al. (2013) used a testing configuration to reduce such problem for a double push test, as shown in Fig. 5. In this testing setup, one side of the concrete specimen is replaced by "a steel U-shaped arm connected to an aluminum cylinder that raps the carbon fiber reinforced polymer (CFRP) middle part to cause bond failure between the FRP sheet and the concrete block fixed to the bottom platen of the machine using special fasteners". [2]

In addition to the unidirectional tests discussed above, beam tests are conducted for the purpose of investigating the mechanism of bond in flexural members, as shown in Fig. 6. One form of a beam test set-up, illustrated in Fig. 6 (a) consists of two pieces of concrete, connected together by a surface bonded material (steel or FRP), forming a simply supported beam, subjected to middle span loading. This set-up can simulate the effects of moment and shear variations along the length of the member.
It was employed by Van Gemert (1980) to investigate the bond behavior of surface bonded steel plates on concrete beams [43]. Ziraba et al. (1995) also used a similar setup to investigate the effects of concrete compressive strength on steel-concrete bond strength [65]. In this case, the researchers used a solid beam, cut a certain depth to create a weak section, with a steel sheet surface bonded over the cut as shown in Fig. 6 (b). They found no dependence of surface joint failure on concrete strength and concluded that the concrete-glue-plate interface behavior was rather a surface phenomenon. However, this contradicted with other experimental observations $[14,51,66,67]$.

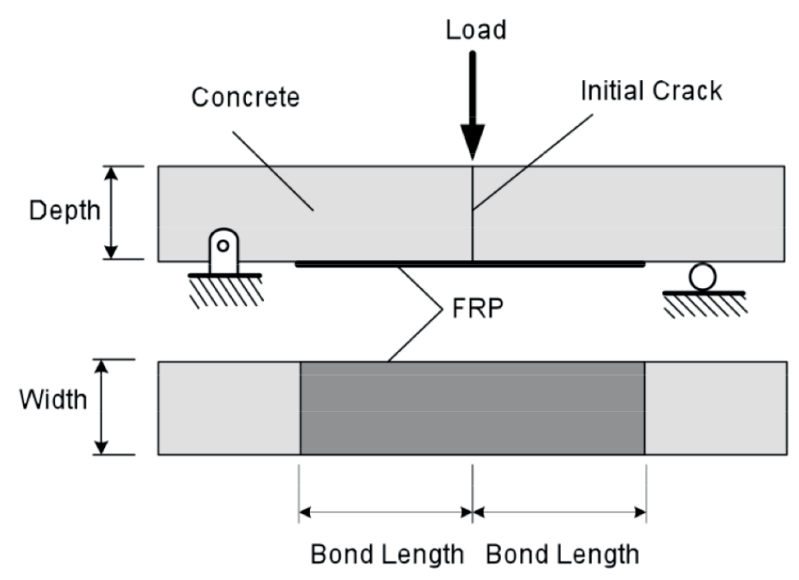

(a ) Chen et al. (2001) [39]

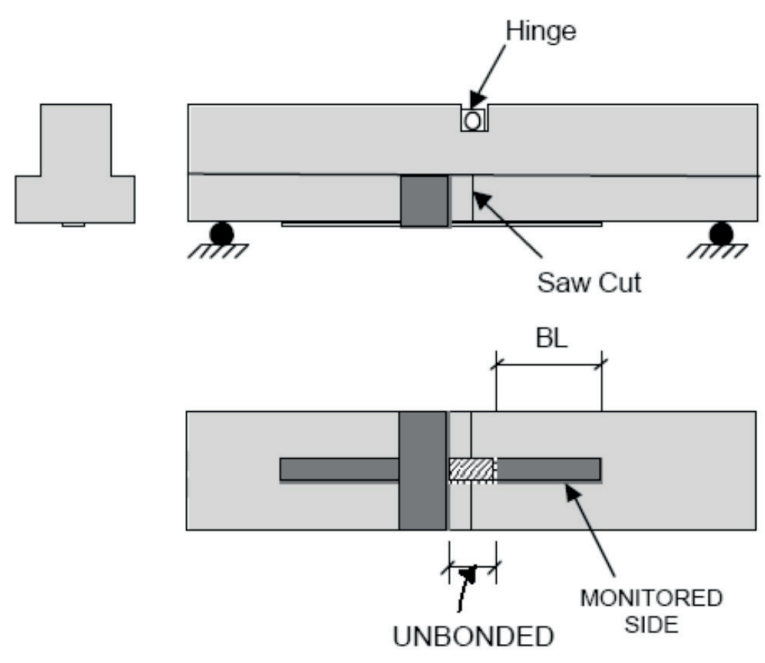

(b) Lorenzis et al. (2001)[66]

Fig. 6 Modified beam bond test method re drawn

Detailed beam specimens are also used for direct shear bond tests simulated by the modified beam tests. These tests were conducted by Chen et al. (2001) [39] and Yao et al. (2005) [37], and reported by Chen et al. (2012), demonstrated in Fig. 7. [68]

Some of the researchers tested the specimens that did not bond the FRP sheet near the loaded end that is called the free zone $[8,69,70]$. Fig. 8 shows this configuration. Most of the researchers tested specimens without the free zone [4, 37, 71]. Mazzoti et al. (2008) compared the behavior of the two testing methods by both experimental and analytical approaches [72]. 


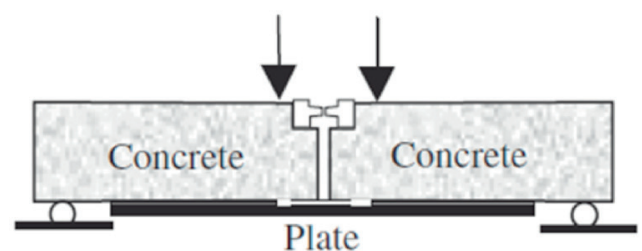

(a) beam test

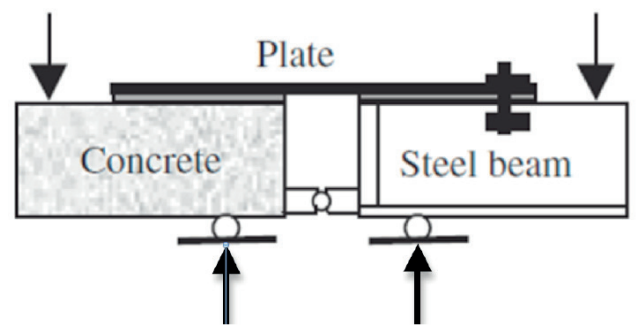

(b) inverted beam test.

Fig. 7 Classification of direct shear bond tests simulated through beam tests (Chen et al. 2012) ([68]

They suggested that the free end setup is slightly better to achieve data for the bond-slip behavior of the interface. If the free zone is not considered or is small, a triangular piece of concrete near the loaded end will be pulled off the concrete prism in the failure time, but this variation in detail does not have a significant effect on the bond-slip behavior on a distance as long as the bond length is not too short [72].

In addition to the above setups and methods of testing, several other techniques were reported in the literature for subjecting interfaces to out-of-plane tension and combination of tension with shear [31, 37-39].

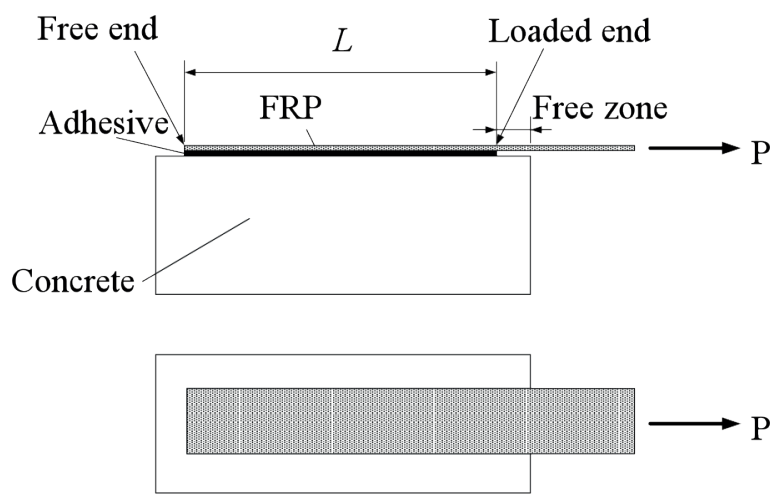

Fig. 8 Schematic of pull test with free zone (Redrawn from Lu et al. 2005b [20])

A new testing setup is suggested in Fig. 9 for double shear pull test. The suggested method is designed to reduce the weight and length of the specimen, while improving the handling of the specimens compared to the typical double shear test using universal testing equipment. The concrete section and the steel assembly are prepared separately. That allows using the steel assembly in multiple tests. In this method the U shape FRP sheets connects the concrete to the thick steel plate welded to a rebar. The bonding load is applied by the pulling force on the bar welded to the steel plate, and the second rebar anchored inside the concrete specimen. The setup allows double shear testing with universal testing machines. The open range of the universal machine may not be appropriate for conventional double shear testing, but can be tested with this setup. The lower weight of the specimen results to ease of handling which is very important in testing. Another benefit of the suggested setup is that smaller concrete form mold is needed for each specimen. The failure is dictated to the concrete side, and the effect of the cracking of concrete in the second side will be eliminated. It also reduces the error of the weight of the top section of the concrete in testing.

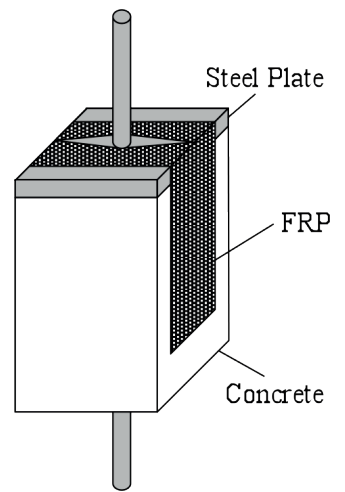

Fig. 9 Suggested double shear pull test setup

\section{Testing Methods and Configurations for Masonry Substrates}

The method shown in fig. 5 was based on the method already used by Briccoli Bati et al. (2009) [73] for testing brick specimens.
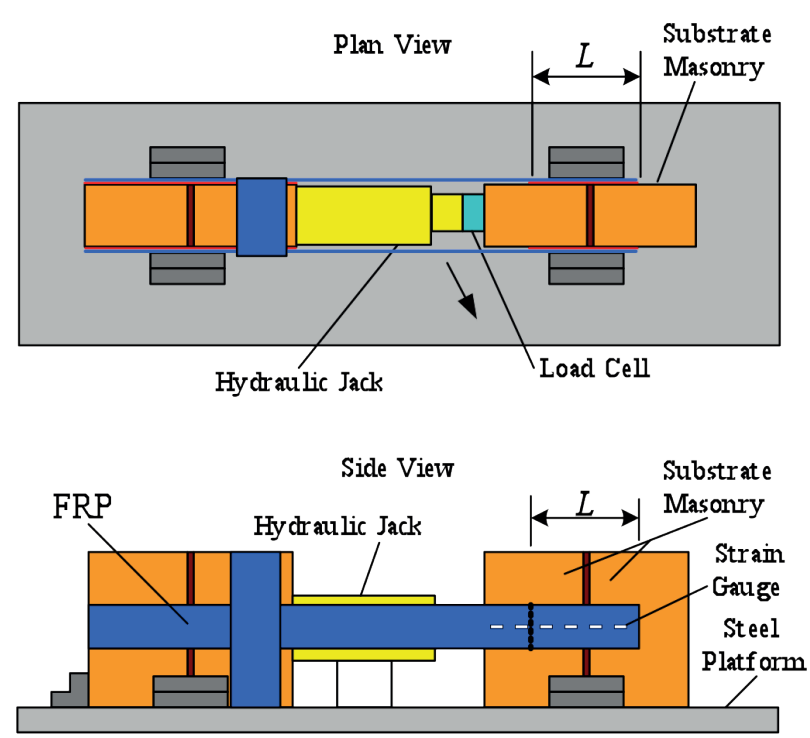

Fig. 10 Setup for testing Brick Specimens, Redrawn from Casareto et al. (2003) [13] 


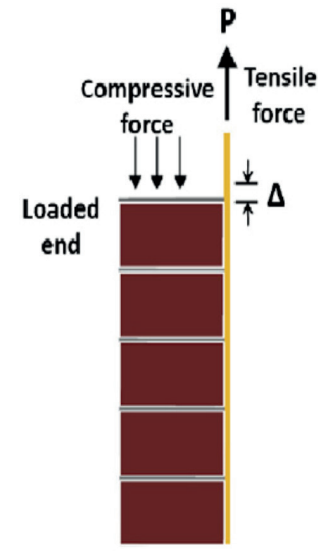

Fig. 11 Pull test simulating IC debonding of a brick wall [78]
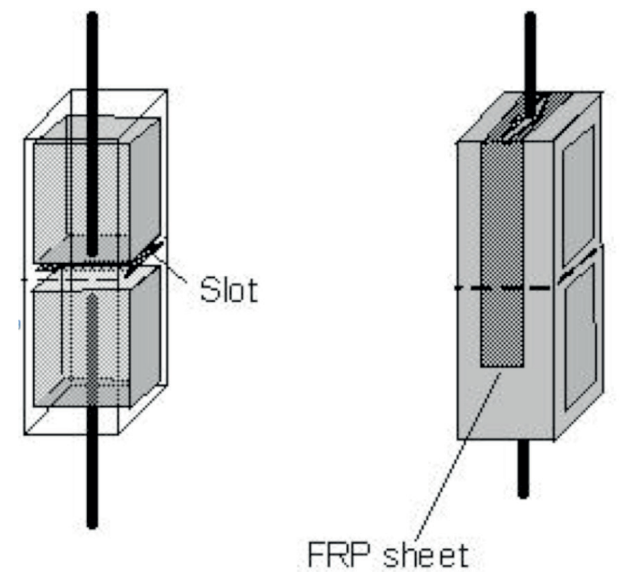

(a) The pull out setup for the concrete blocks specimens. The blocks include separating slot facilitates cracking between two sides

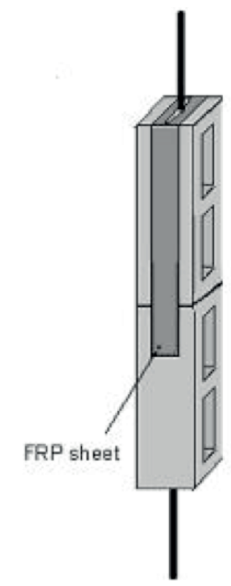

(b) The pull out setup for the brick specimens. Two bricks were attached as shown schematically

Fig. 12 The pull out bond test specimens, for concrete block and brick

Casareto et al. (2003) tested standard hollow concrete blocks and clay brick specimens to investigate the bond behavior of Aramid FRP (AFRP) sheets on different types of masonry surfaces with a double shear push test (Fig. 10) [13]. Ghiassi et al. (2012 and 2013) tested bond behavior of FRP on brick specimens by single shear pushing method and analyzed the behavior [70, 74]. Their setup was single shear pull test similar to the model shown in Fig. 8, with the difference that the substrate material in this setup is brick. Konthesingha et al. (2009), and Liu et al. (2005) used similar approach for testing masonry specimens of brick and concrete block [75, 76]. Briccoli Bati et al. (2009) used the method shown in Fig. 5 for testing brick specimens [73]. Some researchers tested the wall bond behavior of brick walls. Xia and Oehlers (2006), Kashyap et al. (2012), Carloni and Subramanium (2010), and Oliveira et al. (2010) used the single shear push test as demonstrated in Fig. 11 [77-80]. The U-shaped double shear pull test setup was also designed and applied to concrete block and clay brick tests. Fig. 12 shows schematic masonry test specimen setups as prepared and tested by Shadravan (2010) [1]. The method showed to be appropriate for the brick specimens used, but the shape of the low strength concrete block affected the cracking pattern to tensile failure, and could not be used for investigation of the bond behavior.

\section{Data Acquisition Systems}

The experimental data not only provided much needed information for the derivation of analytical expressions for bond length, bond stress and ultimate bond force, but also provided the insight for the development of a complete bond-slip model. Local bond-slip curves from pull tests are commonly determined in two ways; (a) from axial strains of the FRP plate measured with closely spaced strain gauges (e.g. Nakaba et al. 2001a [71]); or (b) from load-displacement (slip at the loaded end) curves (e.g. Ueda et al., 2003 [32]). Most of the researchers use both methods to control the errors and improve the accuracy of results. In the first method, the bond stress of a particular location along the FRP-concrete interface can be found from strain readings, while the corresponding slip can be found through numerical integration of measured longitudinal strains of the plate. The strain gauges are used in the centroidal axis of FRP sheet to receive output from the bond-slip behavior using the typical arrangement of strain gauges. This method appears to be simple, but it cannot produce accurate local bond-slip relationships. This is because the axial strains measured on a thin FRP plate generally show drastic variations as a result of the discrete nature of concrete cracks, the heterogeneity of concrete and the roughness of the underside of the debonded FRP plate. For example, a strain gauge located above a crack will have a much greater strain than that sitting above a large aggregate particle region. Consequently, bond-slip curves found from different tests may differ substantially. The second method is an indirect method and has its own problems as well. In this approach, a local bond-slip curve is determined indirectly from the load-slip relationship. It is easy to show that different local bond-slip curves may lead to similar load-displacement curves $[1,20]$. The pullout load-versus-deformation data are provided by the universal testing machines in double shear tests. Alternatively, most of the single shear bond tests, and some of the double shear testing methods are not tested 
using the universal testing machine. In these testing methods, a loading frame is designed. The load and deformation data can be recorded using load cells and "linear variable differential transformers" (LDVTs) respectively. LVDTs are used to record FRP slip. Fig. 13 demonstrates the typical arrangement of the specimen for single shear push test setup using LVDTs to record slip [60].

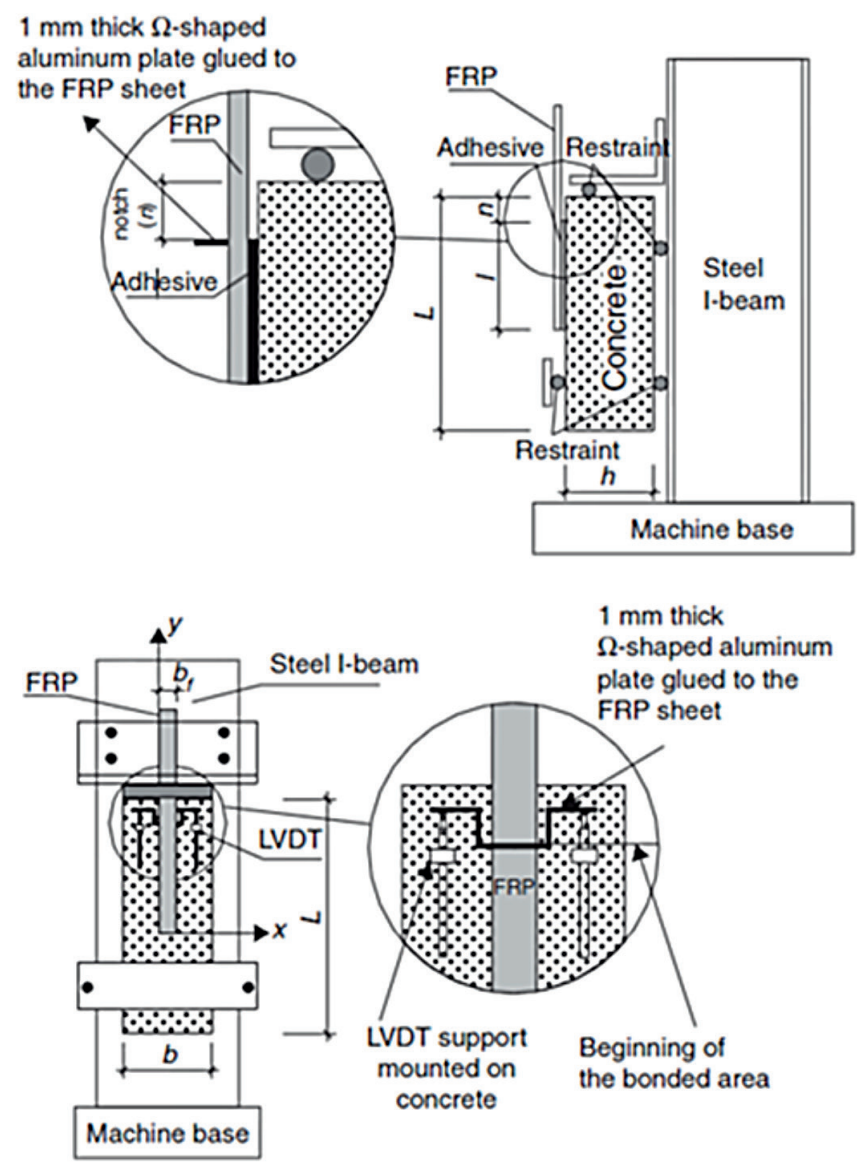

Fig. 13 Specimen dimensions and loading arrangement by using LVDTs [60]

Some researchers use additional strain gauges in the width of FRP sheets to investigate the distribution of the FRP strain and stress in the width $[1,59]$. Other researchers recorded more detailed and accurate surface deformations and strains results using high precision digital camera image acquisition or digital image correlation method on the FRP sheet [81, 74]. Zhao et al. (2007) conducted pull out and beam flexure tests and measured local slip at the interface between concrete and FRP [36]. They used fiber optic sensors with $1 \mathrm{~mm}$ resolution for measurements of local slip at the interface. In flexure, the long gauge distributed sensors were found to provide more precise data, especially during deformation reversals.

\section{Test Observations}

The bond characteristics of surface mounted FRP sheets have been a source of controversy in the past, since lack of sufficient bond between the high-strength FRP sheets and relatively low strength concrete substrate posed challenges in practical applications. A number of experimental research programs have been undertaken to assess the adequacy of bond strength. This section provides a summary of previous experimental findings, while also providing explanation of some of the behavioral aspects of surface bonded FRP sheets on concrete.

It is well established through previous experimental researches that higher stresses are taken up near the critical section while stresses decrease exponentially with distance [10]. A very important aspect of the behavior of these bonded joints is the concept of effective bond length beyond which an extension of the surface-bonded material length cannot effectively increase the ultimate load resistance. This is the fundamental difference between externally bonded reinforcement (as in the case of surface bonded FRP) and internal reinforcement (as in internal rebars embedded in concrete) for which a sufficiently long anchorage length can always be found to attain the full tensile strength of reinforcement. Tensile stresses in FRP are transferred to concrete mainly via bond stresses that develop in the adhesive (epoxy) within a short length near the applied force [16]. Also, the existing studies suggest that the main failure mode of FRP-to-concrete joints is the bond failure of surface concrete that occurs generally within a few millimeters depth from the concrete-to-adhesive interface [33]. Therefore, some of the analytical studies and the resulting bond strength expressions concentrated on concrete fracture mechanics and rupture energy. Bond stress-slip models play a significant role in such studies [19]. The ultimate load (i.e. the maximum transferable load) and the effective bond length of the joint depend on concrete strength. Concrete strengths; including compressive, tensile, and bond strength are used as parameters in some bond models. Indeed, the tests confirmed that the effective bond length tends to decrease with increasing concrete strength. The parameters related to FRP and the dimensions of the substrate (concrete) are considered to be less pronounced. In addition, the FRP sheet-to-substrate width ratio was found to affect bond performance. [11, 17, 20-22, 27, 31-33]

Previous research has also indicated that the shift in the active bond zone can occur under increasing tensile forces. This means that as cracking in concrete propagates, the bond resistance gradually diminishes in regions near the load application point, but in the meantime, it is cracked farther away from the loaded end, as confirmed experimentally [14, 23, 18, 30, 35, 34]. However, a longer bond length may improve the ductility of failure process. This phenomenon is believed to be the primary reason for the observed low stresses in bonded plates at anchorage failure. Existing studies have been mainly concerned with the prediction of ultimate load and the effective bond length, but much less attention has been given to the prediction of the entire debonding process of such bonded joints [16]. 


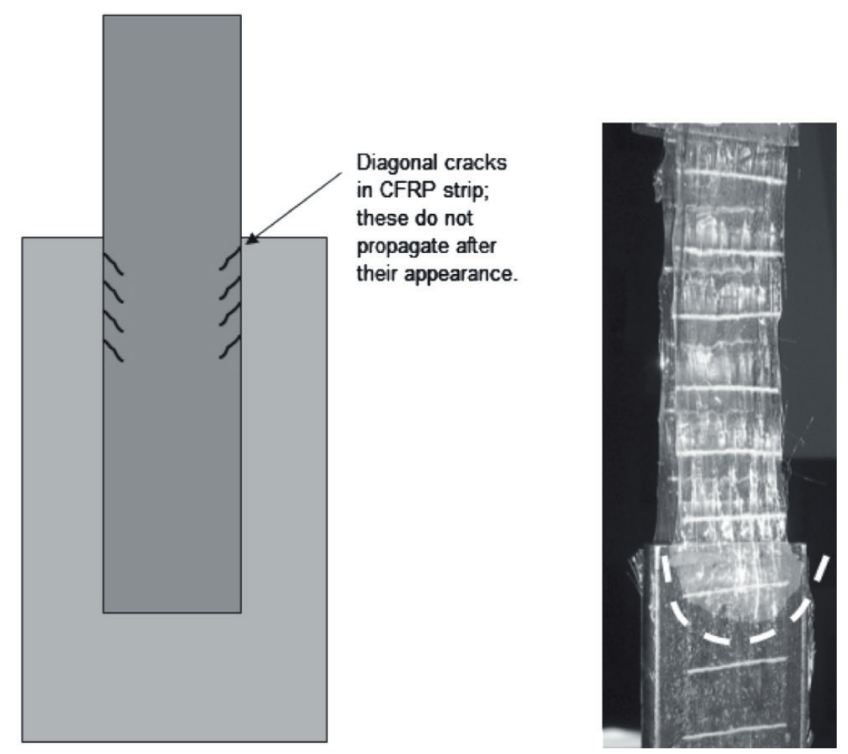

Fig. 14 Exaggerated sketch of edge cracking in CFRP during testing, compared to the edge effects observed in GFRP strips bonded to steel [24]

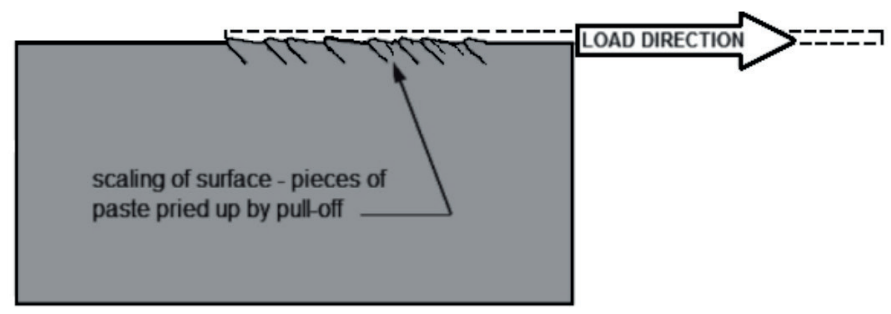

Fig. 15 Concrete surface scaling of dental cracking due to pull-off of the FRP strip [24]

The experimental research in the past have resulted in two major models describing FRP debonding failure in concrete structures; I) cohesive failure in the concrete surface layer, and II) adhesion failure at the adhesive/concrete interface [28]. In general, the debonding of FRP occurs within a thin layer of concrete adjacent to the concrete-to-adhesive interface unless the adhesive is weak. The thickness of this concrete layer is about 2 5mm [21]. McSweeney and Lopez (2005) investigated the sensitivity of FRP-concrete bond failure load to changes in geometric and material parameters [24]. They illustrated the propagation of failure through gradual deterioration of bond. During the initial stages of loading, the specimens do not display signs of distress until the load becomes sufficiently high to cause cracking. At this stage popping sounds can be heard as the load continues to increase. As the final bond failure is approached, cracking sounds become louder and occur at shorter intervals. On occasions, just prior to complete failure, the cracking sound can be heard in a continuous string, analogous to unzipping sound in larger bond lengths. This has been observed in other tests, such as those conducted by Lopez (2000) [25]. These cracks appear at regular intervals, and never propagate significantly inward from the loading end. The angle of cracks suggests an edge effect, affecting the crack propagation, as seen in the crack front of a GFRP strip bonded to steel in Fig. 14. As the bonding failure progresses, small diagonal cracks begin to form along the edges of CFRP strips, as shown in Fig. 15. Each new crack in CFRP strip appears when a shift in crack front occurs as the substrate bond fails. McSweeney and Lopez (2005) reported that as the failure is approached, $86 \%$ of the 42 specimens that they tested developed cracks in the concrete substrate that ran from the edge of the FRP strip up to a point at the leading edge of the concrete block as shown in Fig. 15 depicts these cracks, which resulted in a tooth-like appearance in concrete, near the surface [24]. Rarely did the tooth approach the edge of the shim plate used in the restraint setup - thus, the unrestrained edge distance of $25 \mathrm{~mm}$ between the shim plate and the bonding surface was sufficient to prevent an unrealistic restraint of concrete against failure. The tooth was not visible during testing, but upon final bond failure, the tooth remained bonded to the FRP strip. The concrete cover failure, as part of overall bond failure, has been noted by several researchers $[26,12]$.

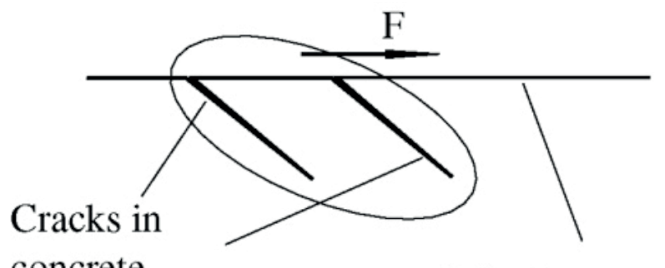
concrete

Adhesive-to-concrete interface

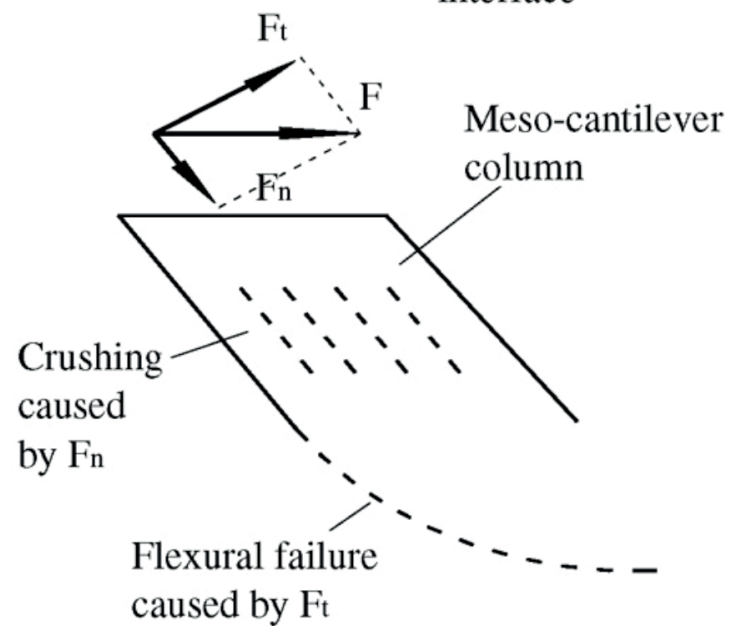

Fig. 16 Meso-cantilever column and its failure modes [83]

The final bond failure of CFRP on concrete was reported by Arduini et al. (1997) and McSweeney and Lopez (2005) to be extremely brittle, and it was accompanied by a large release of energy $[82,24]$. Some of the FRP strips in test specimens were damaged by the energy released at the final failure stage; exhibiting splitting in the longitudinal (fiber) direction, while the epoxy of other strips had post failure transverse cracking. Fragments of concrete often broke loose from the block when the strip broke free (Fig. 15). Increased bond length, width, and thickness led to longer time to failure, but changes to the bond width had the greatest impact on time to failure. For the short 
bond length, there was little warning before the final failure. All other FRP strips provided some warning prior to final bond failure in the form of cracking sounds. While a few specimens experienced pull-out of an additional tooth of concrete at the end of bond length during failure, the vast majority only lost concrete tooth at the leading edge as discussed previously. The remainder of the bonded region, past the leading edge, was free of epoxy after failure, and the FRP strips did not exhibit a significant amount of paste left, clinging to the strip. However, the concrete surface was rough, with numerous microcracks oriented in a manner indicative of the direction of bond failure. A pattern of regularly spaced microcracks was visible throughout the bonded area, with small pieces of paste peeled back by the propagation of bond failure as shown in Fig. 16. This pattern of concrete surface bond cracking is referred as tooth shape, dental cracking, interfacial micro cantilever columns, or micro columns, meso cantilever columns, and microcracks by different researchers (Fig. 16) [24, 22, 83,1]. Other researchers observed similar failure behavior [57]. Shadravan (2010) found loose micro column concrete that could not only be observed, but separated from the failure surface in the specimens tested under cyclic loading [1, 84]. The test results showed that the concrete absorbed more energy and load when the cyclic loading was applied [85].

\section{Conclusions}

The following conclusions can be derived from the review of experimental investigation presented in this paper:

- Different test setups are used for investigation of the bond shear test of FRP sheets on concrete and masonry. They are summarized as single shear, and double shear tests. Each can be pulling or pushing test.

- The different test setups result to slight differences in the results.

- The methods of U shape FRP with one loading side used by steel sheet is suggested for future studies. This pull double shear test has benefits of less weight and ease of handling in comparison to similar testing methods.

- Depending on the test setup, however, some specimens experienced diagonal tension cracking of corners at the critical section. To avoid such failure, longer bond length testing is suggested. Also a free zone is suggested in the loading end of FRP by some researchers to avoid the triangular diagonal tension cracking in shorter bond lengths.

- All of the bond test setups result to the bond cracking which happens in the substrate surface layer adjacent to FRP sheet. The cracking pattern is well known as dental cracking or cantilever micro columns.

- The universal loading machines, and load cells can be used to record the test loading data. Strain gauges, digital camera image acquisition, LVDT, and optic fibers can detect the deformation and slip.

\section{References}

[1] Shadravan, B. "Investigation of surface bond behavior of FRP sheets on concrete and Masonry Substrates.". Ph.D. Thesis, University of Ottawa, Ottawa, Canada. p. 197. 2010. https://doi.org/10.20381/ruor-20046

[2] Haddad, R. H., Al-Rousan, R., Almasry, A. "Bond-slip behavior between carbon fiber reinforced polymer sheets and heat-damaged concrete.”. Composites: Part B: Engineering, 45(1), pp. 1049-1060. 2013. https://doi.org/10.1016/j.compositesb.2012.09.010

[3] Monti, G., Renzelli, M., Luciani, P. "FRP Adhesion in Uncracked and Cracked Concrete Zones.". In: Proceedings of the Sixth International Symposium on FRP Reinforcement for Concrete Structures (FRPRCS-6), Jul. 8-10. Singapore: World Scientific Publishing, 1, pp. 183-192. 2003.

[4] Carloni, C., Subramaniam, K.V., Savoia, M., Mazzotti, C. "Experimental determination of FRP-concrete cohesive interface properties under fatigue loading.". Composite Structures, 94(4), pp. 1288-1296. 2012. https://doi.org/10.1016/j.compstruct.2011.10.026

[5] Dai, J. G., Saito, Y., Ueda, T., Sato, Y. "Static and Fatigue Bond Characteristics of Interfaces between CFRP Sheets and Frost Damage Experienced Concrete.". In: FRPRCS-7. Kansas City, MO. Nov. 6-9. 2005. pp. 1515-1530. 2005.

[6] Nizic A., Niedermeier, R., Zilch, K. "Behavior of externally bonded reinforcement under low cycle fatigue loading.". In: Proceedings of the 9th International Symposium of the Fiber-Reinforced Polymer Reinforcement for Reinforced Concrete Structures (FRPRCS-9), Jul. 13-15. Sydney, Australia. p. 287. 2009.

[7] Tommaso, D., Neubauer, A., Pantuso, A., Rostasy, F. S. "Behavior of Adhesively Bonded Concrete-CFRP Joints at Low and High Temperatures". Mechanics of Composite Materials, 37(4), pp. 327-338. 2001. https://doi.org/10.1023/A:1012392703519

[8] Ahmed, A., Kodur, V. K. R. "Effect of bond degradation on fire resistance of FRP-strengthened reinforced concrete beams.". Composites Part B: Engineering, 42(2), pp. 226-237. 2011. https://doi.org/10.1016/j. compositesb.2010.11.004

[9] Subramaniam, K. V., Ali-Ahmad, M., Ghosn, M. "Freeze-thaw degradation of FRP-concrete interface: Impact on cohesive fracture response". Engineering Fracture Mechanics, 75(13), pp. 3924-3940. 2008. https:// doi.org/10.1016/j.engfracmech.2007.12.016

[10] Buyukozturk, O., Au, C. "Failure behaviour of FRP bonded concrete affected by interface fracture, Part 2. Moisture Degradation in FRP Bonded Concrete Systems: An Interface Fracture Approach”. IST Group 2004.

[11] Shadravan, B., Saatcioglu, M., Foo, S. "An investigation on the bond length of FRP sheets on concrete substrate". $8^{\text {th }}$ International Symposium on Fiber Reinforced Polymer Reinforcement for Concrete Structures, University of Patras, Patras, Greece 2007.

[12] Buyukozturk, O., Hearing, B. "Failure Behaviour of Precracked Concrete Beams Retrofitted with FRP”. Journal of Composites for Construction, 2(3), pp. 138-144. 1998.

[13] Casareto, M., Oliveri, A., Romelli, A., Lagomarsino, S. "Bond behavior of FRP laminates adhered to masonry Advancing with Composites". Plast, 2003; rb2c.mst.edu.

[14] Chajes, M. J., Finch, W. W. Jr, Januszka, T. F., Thomson, T. A. "Bond and Force Transfer of Composite Material Plates Bonded to Concrete". ACI Structural Journal, 93(2), pp. 295-303. 1996. https://doi. org/10.14359/1491

[15] Chen, J. F, Pan, W. K. "Three dimensional stress distribution in FRPto-concrete bond test specimens". Construction and Building Materials, 20(1-2), pp. 46-58. 2006. https://doi.org/10.1016/j.conbuildmat.2005.06.037 
[16] Chen, J. F., Teng, J. G. "Anchorage strength models for FRP and steel plates bonded to concrete". Journal of Structural Engineering, 127(7), pp. 784-791. 2001. https://doi.org/10.1061/(ASCE)07339445(2001)127:7(784)

[17] Dai, J. G. "Interfacial models for fiber reinforced polymer (FRP) sheets Externally bonded to concrete.”. 2006. http://www.egr.msu.edu/firestruct/Fire\%20Research\%20PhD/Interfacial\%20Models\%20for\%20 FRP\%20Sheets\%20Externally $\% 20$ Bonded $\% 20$ to $\% 20$ Concrete $\% 20$ by\%20Dai\%20Jian\%20Guo.pdf

[18] Holzenämpfer, P. "Ingenieurmodelle des Verbundes geklebter Bewehrung für Betonbauteile”. Dissertation, TU Braunschweig, Germany 1994.

[19] Karbhari, V. M., Niu, H., Sikorsky, C. "Review and Comparison of Fracture Mechanics-based Bond Strength Models for FRP-strengthened Structures". Journal of Reinforced Plastics and Composites, 25(17), pp. 1757-1794. https://doi.org/10.1177/0731684406074475

[20] Lu, X. Z., Teng, J. G., Ye, L. P., Jiang J. J. "Bond-slip models for FRP sheets/plates bonded to concrete". Engineering Structures, 27(6), pp. 920-937. 2005. https://doi.org/10.1016/j.engstruct.2005.01.014

[21] Lu, X. Z., Teng, J. G., Ye, L. P., Jiang, J. J. "Bond-slip models for FRP sheets/plates bonded to concrete". In: Proceedings of 2 nd international Conference of advanced polymer composites for structural applications in construction (ACIC2004).

[22] Lu, X. Z., Yan, J. J., Wei, H., Ye, L. P., Jiang, J. J. "Discussion on the key difficulties of finite element analysis for the interface between FRP sheet and concrete". In: Proceedings of the 2nd National Civil Engineering Forum of graduate students of China. pp. 134-137. 2004.

[23] Maeda, T., Asano, Y., Sato, Y., Ueda, T., Kakuta, Y. "A Study on Bond Mechanism of Carbon Fiber Sheet, Non-Metallic FRP Reinforcement for Concrete Structures". Japan Concrete Institute, Japan, 1997; 1, pp. 279-286.

[24] McSweeney, B. M., Lopez, M. M. "FRP-Concrete Bond Behavior: A Parametric Study Through Pull-Off Testing". In: FRPRCS-7. Kansas City, MO. Nov. 6-9. 2005. pp. 441-460. 2005.

[25] Lopez, M. M. "Study of the Flexural Behaviour of Reinforced Concrete Beams Strengthened by Externally Bonded Fiber Reinforced Polymeric (FRP) Laminates.”. Ph.D. Thesis University of Michigan, 2000.

[26] Lopez, M.M., Naaman, A.E. "Concrete Cover Failure or Tooth Type Failure in RC Beams Strengthened with FRP Laminates.”. In: FRPRCS-6. Proc. of the Sixth International Symposium on FRP Reinforcement for Concrete Structures. (Kiang Hwee Tan (Ed.)). Jul. 8-10. Singapore. 2003. pp. 317-326. 2003.

[27] Oehlers, D. J., Seracino, R. "Design of FRP and steel plated RC structures." Retrofitting Beams and Slabs for Strength, Stiffness and Ductility". Elsevier, 2004.

[28] Ouyang, Z., Wan, B. "Experimental and Numerical Study of Moisture Effects on the Bond Fracture Energy of FRP/Concrete Joints". Journal of reinforced plastics and composites, 27(2), pp. 205-223. 2008. https:// doi.org/10.1177/0731684407082952

[29] Serrato, F. "Seismic retrofit of URM Infill Panels in reinforced concrete frames using FRP sheets.”. M.Sc. Thesis, Civil Engineering, university of Ottawa, 2002.

[30] Täljsten, B. "Defining Anchor Lengths of Steel and CFRP Plates Bonded to Concrete". International Jourbal of Adhesion and Adhesives, 17(4), pp. 319-327. 1997. https://doi.org/10.1016/S0143-7496(97)00018-3

[31] Teng, J. G., Chen, J. F., Smith, S. T., Lam, L. "FRP Strengthened RC structures". Wiley, 2001.

[32] Ueda, T., Dai, J. G., Sato, Y. "A nonlinear bond stress-slip relationship for FRP sheet-concrete interface.". In: International symposium on latest achievement of technology and research on retrofitting concrete structures : proceedings and technical report on JCI Technical Committee : July 14-15, Kyoto. 2003. pp. 113-120. 2003.
[33] Yuan, H., Teng, J. G., Seracino, R., Wu, Z. ., Yao, J. “Full- range behavior of FRP-to-concrete bonded joints”. Engineering Structures, 26(5), pp. 553-565. 2004. https://doi.org/10.1016/j.engstruct.2003.11.006

[34] Yuan, H., Wu, Z. S., Yoshizawa, H. "Theoretical Solutions on Interfacial Stress Transfer of Externally Bonded Steel/Composite Laminates". JSCE Journal of Structural Mechanics and Earthquake Engineering, 18(1), pp. 27-39. 2001.

[35] Yuan, H., Wu, Z. "Interfacial fracture theory in structures strengthened withcomposite of continuous fiber.". Proceedings, Symposium of China and Japan, Science and Technology of $21^{\text {st }}$ Century, Tokyo, Japan 1999; pp. 142-55.

[36] Zhao, M, Dong, Y., Zhao, Y., Tennant, A, Ansari, F. "Monitoring of Bond in FRP Retrofitted Concrete Structures". Journal of Intelligent material systems and structures, 18(8), pp. 853-860. 2007. https://doi. org/10.1177/1045389X06074571

[37] Yao, J., Teng, J. G., Chen, J. F. "Experimental study on FRP to concrete bonded joints". Composites Part B: Engineering, 36(2), pp. 99-113. 2005. https://doi.org/10.1016/j.compositesb.2004.06.001

[38] Nakaba, K., Kanakubo, T., Furuta, T., Yoshizawa, H. "Bond Behavior between Fiber-Reinforced Polymer Laminates and Concrete". $A C I$ Structural Journal, 98(3), pp. 359-367. 2001.

[39] Chen, J. F., Yang, Z. J., Holt, G. D. "FRP or steel plate-to-concrete bonded joints: Effect of test methods on experimental bond strength". Steel Composite Structures. An International Journal, 1(2), pp. 231-244. 2001.

[40] Ueda, T., Dai, J. "Interface bond between FRP sheets and concrete substrates: properties, numerical modeling and roles in member behavior.". Progress in Structural Engineering and Materials, 7(1), pp. 27-43. 2005. https://doi.org/10.1002/pse.187

[41] Cornetti, P., Carpinteri, A. "Modeling the FRP-concrete delamination by means of an exponential softening law". Engineering Structures, 33(6), pp. 1988-2001. 2011. https://doi.org/10.1016/j.engstruct.2011.02.036

[42] Ko, H., Matthys, S., Palmieri, A., Sato, Y. "Development of a simplified bond stress-slip model for bonded FRP-concrete interfaces". Construction and Building Materials, 68, pp. 142-157. 2014. https://doi. org/10.1016/j.conbuildmat.2014.06.037

[43] Van Gemert, D. "Force transfer in epoxy-bonded steel-concrete joints.". International Journal of Adhesion and Adhesives, 1(2), pp. 67-72. 1980. https://doi.org/10.1016/0143-7496(80)90060-3

[44] Kobatake, Y., Kimura, K., Katsumata, H. "A retrofitting method for reinforced concrete structures using carbon fibre. Fibre-reinforced-plastic (FRP) reinforcement for concrete structures: properties and applications.”. Amsterdam: Elsevier 1993; pp. 435-50.

[45] FORCA tow sheets technical notes. Autocon Composites Inc.,New York, 1994.

[46] Yoshizawa, H., Myojo, T., Okoshi, M., Mizukoshi, M., Kliger, H. S. "Effect of Sheet Bonding Condition on Concrete Members Having Externally Bonded Carbon Fiber Sheet". In: Fourth Materials Engineering Conference, ASCE, Washington D.C. pp.1608-1616. 1996.

[47] Brosens, K., Van Gemert, D. "Anchoring Stresses between Concrete and Carbon Fibre Reinforced Laminates, Non-Metallic (FRP) Reinforcement for Concrete Structures". In: 3rd International Symposium, Japan Concrete Institute. Sapporo, Japan. 1, pp. 271-278. 1997.

[48] Hiroyuki, Y., Wu, Z. "Analysis of debonding fracture properties of CFS strengthened member subject to tension. Non-Metallic (FRP) Reinforcement for Concrete Structures". In: Proceedings of the 3rd International Symposium, Tokyo, Japan, Concrete Institute 1997, 1, pp. 287-294. 1997.

[49] Fuzukawa, K., Numao, T., Wu, Z., Yoshizawa, H., Mitsui, M. "Critical strain energy release rate of interface debonding between carbon fibre sheet and mortar. Non-Metallic (FRP) Reinforcement for Concrete Structures“. In: Proceedings of the 3rd International Symposium, Tokyo, Japan. Japan Concrete Institute; 1997, 1, pp. 295-302. 1997. 
[50] Izumo, K., Saeki, N., Asamizu, T., Shimura K. "Strengthening reinforced concrete beams by using prestressed fiber sheets". In: Proceedings of the 3rd International Symposium on Non-Metallic (FRP) Reinforcement for Concrete Structures. Sapporo, Japan, Oct. 14-16. 1997. 1, pp. 379-386. 1997.

[51] Horiguchi, T., Saeki, N. "Effect of Test Methods and Quality of Concrete on Bond Strength of CFRP Sheet". Non-Metallic (FRP) Reinforcement for Concrete Structures, In: Proceedings of the 3rd International Symposium on Non-Metallic (FRP) Reinforcement for Concrete Structures. Sapporo, Japan, Oct. 14-16. 1997. 1, pp. 265-270. 1997.

[52] Ueda T, Sato Y, Asano Y. "Experimental study on bond strength of continuous carbon fiber sheet." In: Fourth International Symposium on Fiber Reinforced Polymer Reinforcement for Reinforced Concrete Structures. American Concrete Institute, Detroit, MI, 1999. Report/Paper Numbers: SP-188-37. pp. 407-416. 2000.

[53] Täljsten, B. "Plate Bonding. Strengthening of existing concrete structures with epoxy bonded plates of steel or fiber reinforced plastics.". Doctoral Thesis, Luleå University of Technology, Sweden 1994.

[54] Chajes, M. J., Januszka, T. F., Mertz, D. R., Thomson, T. A., Finch W.W. "Shear strengthening of reinforced concrete beams using externally applied composite fabrics". ACI Structural Journal, 92(3), pp. 295-303. 1995. https://doi.org/10.14359/1130

[55] Bizindavyi, L., Neale, K. W. "Experimental and theoretical investigation of transfer lengths for composite laminates bonded to concrete.". Proceedings, Annual Conference of Canadian Society for Civil Engineering, Structures-Composite Materials, Structural Systems Telecommunication Towers, Sherbrooke, Que' bec, Canada; 1997; V6 pp. 51-60.

[56] Bizindavyi, L., Neale, K.W. "Transfer lengths and bond strengths for composites bonded to concrete.". Journal of Composites for Construction, 3(4), pp. 153-60. 1999. https://doi.org/10.1061/(ASCE)10900268(1999)3:4(153)

[57] Mazzotti, C., Savoia, B. Ferracuti. "A new single-shear set-up for stable debonding of FRP-concrete joints.". Construction and Building Materials, 23(4), pp. 1529-1537. 2009. https://doi.org/10.1016/j.conbuildmat.2008.04.003

[58] Iovinella, I., Prota, A., Mazzotti, C. "Influence of surface roughness on the bond of FRP laminates to concrete." Construction and Building Materials, 40, pp. 533-542. 2013. https://doi.org/10.1016/j.conbuildmat. 2012.09.112

[59] Bilotta, A., Di Ludovico, M., Nigro, E. "FRP-to-concrete interface debonding: Experimental calibration of a capacity model." Composites Part B: Engineering, 42(6), pp. 1539-1553. 2011. https://doi.org/10.1016/j. compositesb.2011.04.016

[60] Carloni, C., Subramaniam, K. V. "Application of fracture mechanics to debonding of FRP from RC members." In: $A C I$ 2012b; SP 286-10, A Fracture Approach for FRP-Concrete Structures. (Carloni, C., Lopez, M. (Eds.)) pp. 1-16. 2012.

[61] Swamy, R. N., Jones, R., Charif, A. "Shear adhesion properties of epoxy resin adhesives.". In: Adhesion between polymers and concrete. (Sasse, H. R. (Ed.)). Springer Science. 1986. pp. 741-755. 1986. http://link. springer.com/chapter/10.1007\%2F978-1-4899-3454-3_69\#page-1

[62] Neubauer, U., Rostasy, F. S. "Design Aspects of Concrete Structures strengthened with Externally Bonded CFRP Plates, Concrete and Composites.". In: Proceedings of the 7th International Conference on Structural Faults and Repair. Edinburgh, 1997 of Conference. ECS Pub. Edinburgh, Scotland. 1997. 2, pp. 109-118.

[63] ACI440.2.R-08. "Guide for the design and construction of externally bonded FRP systems for strengthening concrete structures.”. ACI, 2008.

[64] Canadian Standard Association, "CSA S806-02 Design and construction of Building Components with Fibre-Reinforced Polymers.". Toronto, ON, Canada, 2002, 178p.
[65] Ziraba, Y. N., Baluch, M. H., Basunbul, A. M., Azad, A. K., Al-Sulaimani, G. J., Sharif, I. A. "Combined experimental-numerical approach to characterization of steel-glue-concrete interface.". Materials and Structures, 28(9), pp. 518-525. 1995. https://doi.org/10.1007/BF02473156

[66] Lorenzis, L., Miller, B., Nanni A. "Bond of FRP Laminates to Concrete.”. ACI Materials Journal, 98(3), pp. 256-264. 2001.

[67] Dai, J., Ueda, T., Sato, Y. "Development of the Nonlinear Bond StressSlip Model of Fiber Reinforced Plastics Sheet-Concrete Interfaces with a Simple Method.". Journal of Composites for Construction, 9(1), pp. 52-62. 2015. https://doi.org/10.1061/(ASCE)1090-0268(2005)9:1(52)

[68] Chen, G. M., Chen, J. F., Teng, J. G. "Behavior of FRP-to-concrete interfaces between two adjacent cracks: A numerical investigation on the effect of bondline damage.". Construction and Building Materials, 28(1), pp. 584-591. 2012. https://doi.org/10.1016/j.conbuildmat.2011.08.074

[69] Tan, Z. "Experimental research for RC beam strengthened with GFRP.". Master thesis, China, Tsinghua University, 2002.

[70] Ghiassi, B., Marcari, G., Oliveira, D.V., Lourenço, P.B. "Numerical analysis of bond behavior between masonry bricks and composite materials.". Engineering Structures, 43, pp. 210-220. 2012. https://doi. org/10.1016/j.engstruct.2012.05.022

[71] Nakaba, K., Toshiyuki, K., Tomoki, F., Hiroyuki, Y. "Bond behavior between fiber-reinforced polymer laminates and concrete.”. ACI Structural Journal, 98(3), pp. 359-367. 2001.

[72] Mazzotti, C., Savoia, M., Ferracuti, B. "An experimental study on delamination of FRP plates bonded to concrete.". Construction and Building Materials, 22(7), pp. 1409-1421. 2008. https://doi.org/10.1016/j.conbuildmat.2007.04.009

[73] Briccoli Bati, S., Rovero, L., Tonietti, U. "Adhesion tests between brick and CRFRP strtip.". In: Proceedings of the 9th International Symposium of the Fiber-Reinforced Polymer Reinforcement for Reinforced Concrete Structures (FRPRCS-9). Jul. 13-19. Sydney, Australia. 2009.

[74] Ghiassi, B., Xavier, J., Oliveira, D.V., Lourenço, P. B. "Application of digital image correlation in investigating the bond between FRP and masonry.". Composite Structures, 106, pp. 340-349. 2013. https://doi. org/10.1016/j.compstruct.2013.06.024

[75] Konthesingha, K. M. C., Masia, M. J., Petersen, R. B., Page, A. W. "Bond behavior of NSM FRP strips to modern clay brick masonry prisms under cyclic loading.". $11^{\text {th }}$ Canadian masonry symposium, Toronto, Ontario, May 31-Jun. 3. 2009. http://canadamasonrydesigncentre.com/download/ symposium(2)/A5-3.pdf

[76] Liu, Y., Dawe, J., McInerney, J. "Behavior of GFRP sheets bonded to masonry walls.". In: Proceedings of the International Symposium on Bond Behaviour of FRP in Structures (BBFS 2005). pp. 473-480. 2005.

[77] Xia, S., Oehlers, D. J. "Debonding mechanisms in FRP plated unreinforced masonry under out-of-plane loading.". Advances in Structural Engineeering, 9(6), pp. 619-37. 2006. https://doi.org/http://dx.doi. org/10.1260/136943306778827565

[78] Kashyap, J., Willis, C.R., Griffith, M.C., Ingham, J.M., Masia, M.J. "Debonding resistance of FRP-to-clay brick masonry joints.". Engineering Structures, 41, pp. 186-198. 2012. https://doi.org/10.1016/j.engstruct.2012.03.032

[79] Carloni, C., Subramaniam, K.V. "Direct determination of cohesive stress transferduring debonding of FRP from concrete.". Composite Structures, 93(1), pp. 184-192. 2010. https://doi.org/10.1016/j.compstruct.2010.05.024

[80] Oliveira, D. V, Basilio, I, Lourenço, P. B. "Experimental bond behavior of FRP sheets glued on brick masonry.". Journal of Composites for Construction, 15(1), pp. 32-41. 2011. https://doi.org/10.1061/(ASCE) CC.1943-5614.0000147 
[81] Subramaniam, K. V., Ali-Ahmad, M., Ghosn, M. "Freeze-thaw degradation of FRP-concrete interface: Impact on cohesive fracture response.". Engineering Fracture Mechanics, 75(13), pp. 3924-3940. 2008. https:// doi.org/10.1016/j.engfracmech.2007.12.016

[82] Arduini, M., Di Tommaso, A., Nanni, A. "Brittle failure in FRP plate and sheet bonded beams.”. ACI Structural Journal, 94(5), pp. 363-370. 1997.

[83] Lu, X. Z., Ye, L. P., Teng, J. G., Jianga, J. J. “Meso-scale finite element model for FRP sheets/plates bonded to concrete.". Engineering Structures, 27(4), pp. 564-575. 2005. https://doi.org/10.1016/j.engstruct.2004.11.015
[84] Shadravan, B., Saatcioglu, M. "The effect of cyclic loading on performance of surface bonded FRP sheets on concrete". In: Proceedings of the 9th International Symposium of the Fiber-Reinforced Polymer Reinforcement for Reinforced Concrete Structures (FRPRCS-9). Jul. 13-19. Sydney, Australia. 2009.

[85] Shadravan, B., Saatcioglu, M. "Surface bond characteristics of FRP sheets for seismic retrofit applications.”. In: 9th US National and 10th Canadian Conference on Earthquake Engineering 2010. Toronto, Ontario, Canada. Jul. 25-29. 2010. 1, pp. 215-224. 2010. 